\title{
Hypertrophic pulmonary osteoarthropathy in association with pulmonary metastases from extrathoracic tumours
}

\author{
M. H. YACOUB ${ }^{1}, G$. SIMON, AND J. OHNSORGE \\ From the Brompton Hospital, London S.W.3
}

Three cases of pulmonary osteoarthropathy secondary to pulmonary metastases from extrathoracic tumours are described. Analysis of the reported cases shows that most of them were secondary to osteosarcoma, nasopharyngeal tumour, fibrosarcoma, and uterine tumour. Fibrous tumours and tumours with a predominantly fibrous stroma tend to be associated with osteoarthropathy more than others. This suggests that the fibrous stroma may be a factor in the stimulation of the reflex mechanism responsible for osteoarthropathy.

Pulmonary osteoarthropathy was first described by Bamberger (1889) and Marie (1890) in association with intrathoracic inflammatory lesions. A few years later Virchow (1895) described a patient suffering from pulmonary osteoarthropathy secondary to lung metastases from chondrosarcoma of the humerus. The association of osteoarthropathy with bronchial carcinoma was first reported by Thompson (1904). With the marked increase in the incidence of bronchial carcinoma, this condition has become recognized as the main cause of pulmonary osteoarthropathy (Craig, 1937 ; Van Hazel, 1940 ; Berg, 1949; Editorial, 1954; Vogl, Blumenfeld, and Gutner, 1955; Semple and McCluskie, 1955 ; Coury, 1960 ; Yacoub, 1965b). That metastatic tumours of the lung can also be associated with osteoarthropathy is not widely recognized (Aufses and Aufses, 1960). The relationship between the site of the primary tumour and the incidence of pulmonary osteoarthropathy has not been described before. The purpose of this paper is to report three cases of pulmonary osteoarthropathy secondary to pulmonary metastases from extrathoracic tumours and to analyse the previously reported cases.

\section{CASE REPORTS}

CASE 1 D. H., a man aged 29, had a mole on the right thigh which had been getting bigger for the last few months. This was treated by local excision in May 1960. Histological examination showed 'an

'Present address: National Heart Hospital, London, W.1 intradermal melanoma with some junctional aotivity' In July 1960 he had a local recurrence whigh measured $2 \mathrm{~cm}$. in diameter with two small satellife nodules. These were treated by wide excision of the mole and the surrounding tissues, including the des fascia. He also had an enlarged hard lymph node $\frac{2}{\mathrm{~m}}$ the right groin; this was treated by block dissection of the groin in August 1960. Histological examination of the excised mole showed a 'malignant mela noma infiltrating the subcutaneous tissue'. A ches. radiograph showed no evidence of pulmonaty mətastasis.

In July 1961 a local recurrence was treated by regional perfusion using melphalan (phenylalaniole mustard).

In July 1962 he complained of severe pain in the lefit elbow with effusion into the joint. Repeated radiographs showed no bony metastasis. In April 1963 Be was found to have gross clubbing of the fingers and toes with painful swelling of the ankles and wrists. A chest radiograph (Fig. 1) showed two roumd opacities, one in the right upper lobe and the other in the left mid-zone. A few months later the joint pains became very severe and incapacitating. THe chest radiograph showed multiple bilateral pulmonany metastases. He died in September 1965 from cerobral metastases. Post-mortem examination showed disseminated metastases; histologically the tumours in the lungs resembled the primary tumour except the absence of pigment (amelanotic metastasis).

CASE 2 W. S., a man aged 42, was admitted to hơpital on 21 June 1948. He had had painful swellings of the ankles and knees for three months. He vas found to have marked clubbing of the fingers and toes with swelling of the distal thirds of the arms and legs. He also had bilateral effusions in the ktree 


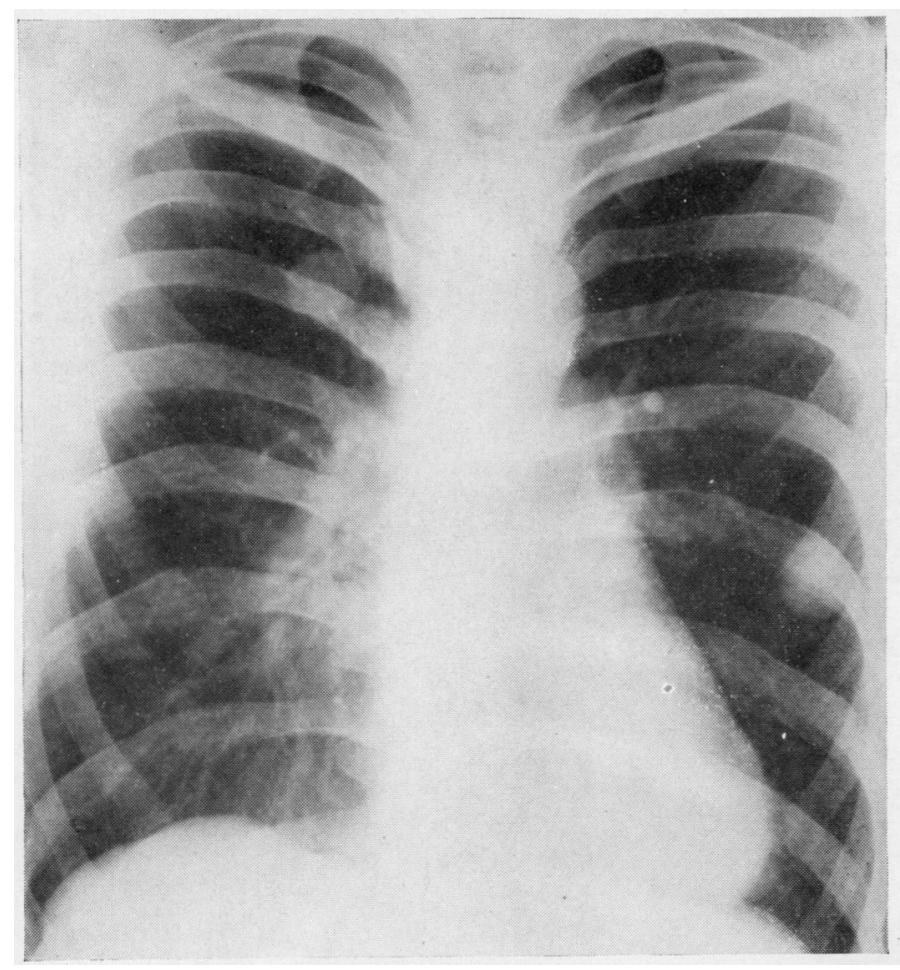

FIG. 1. Case 1. Chest radiograph shows two round opacities, one in the right upper lobe and the other in the left mid-zone.

FIG. 2. Case 2. Chest radiograph shows a round opacity in the right upper lobe.

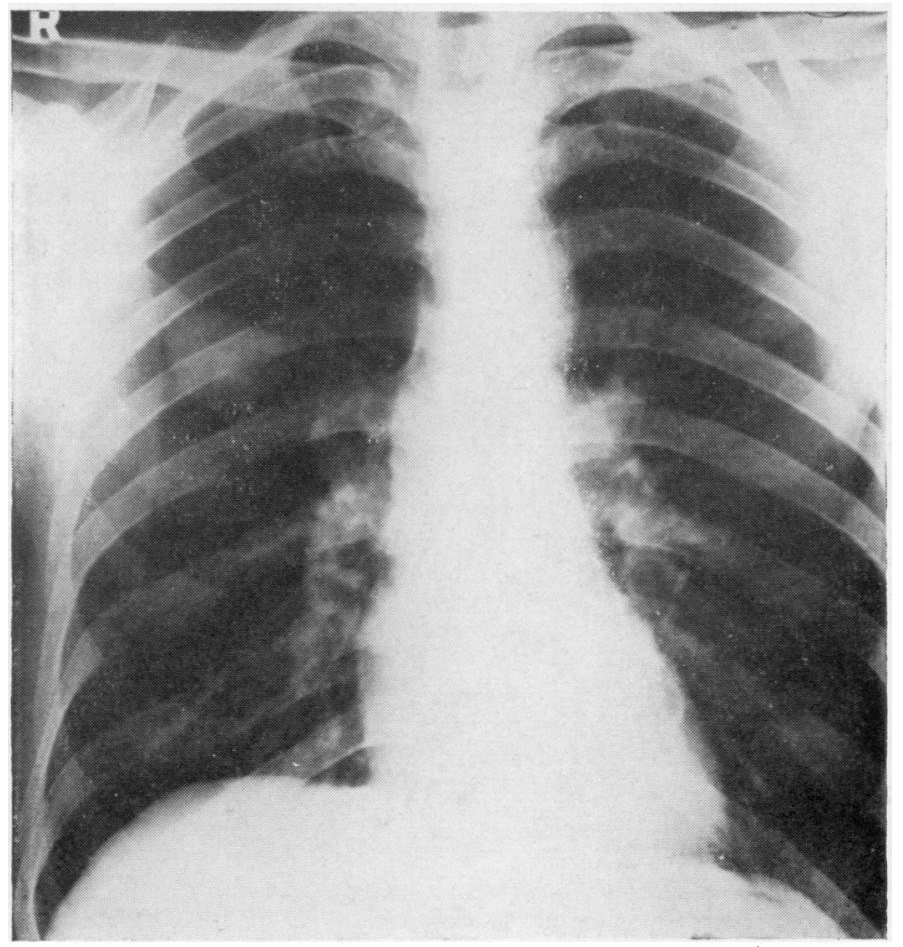


joints. A chest radiograph (Fig. 2) showed a round opacity in the right upper lobe; radiographs of the long bones showed subperiosteal new bone formation. Right pneumonectomy was performed on 24 June 1948. Histological examination of the excised specimen showed a columnar-cell adenocarcinoma, suggesting a metastasis from the gastro-intestinal tract. The joint pains were immediately relieved after operation, but his general condition continued to deteriorate and he complained of anorexia. A firm mass was felt in the right hypochondrium. A barium meal on 11 October 1948 (Fig. 3) showed an advanced carcinoma of the pyloric end of the stomach. He died on 28 January 1949.

COMMENT The lesion in the upper lobe of the right lung was thought to be a primary carcinoma ; histological examination suggested a secondary deposit from the gastro-intestinal tract. This was confirmed by the clinical and radiographic evidence of carcinoma of the stomach.

CASE 3 A. M., a woman aged 27, was found to have advanced pulmonary osteoarthropathy with extensive subperiosteal new bone formation (Fig. 4). Osteosarcoma of the tibia had been treated by above-knee

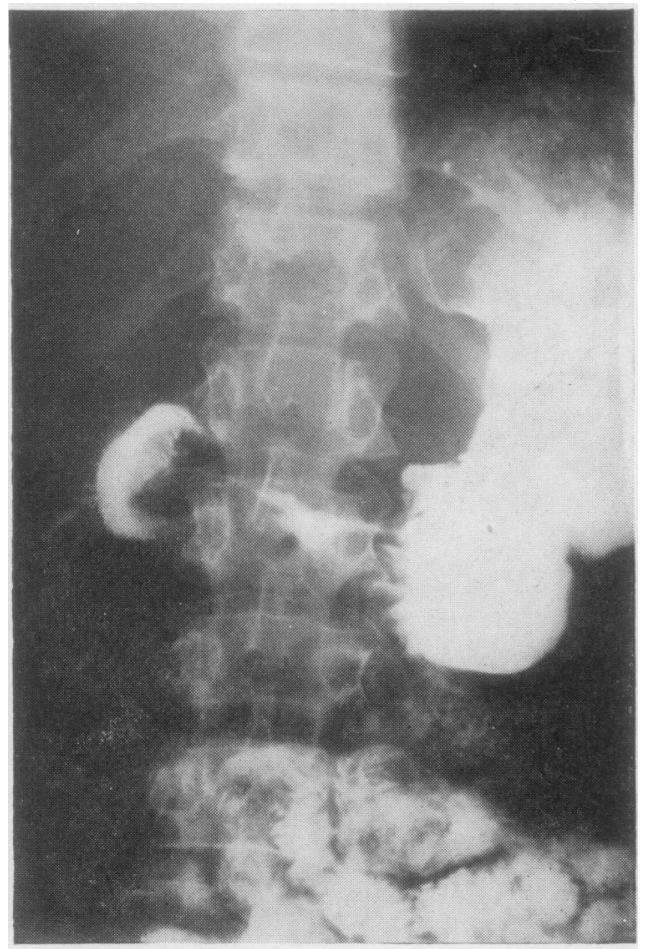

FIG. 3. Case 2. Barium meal shows an irregular filling defect in the pyloric region of the stomach.

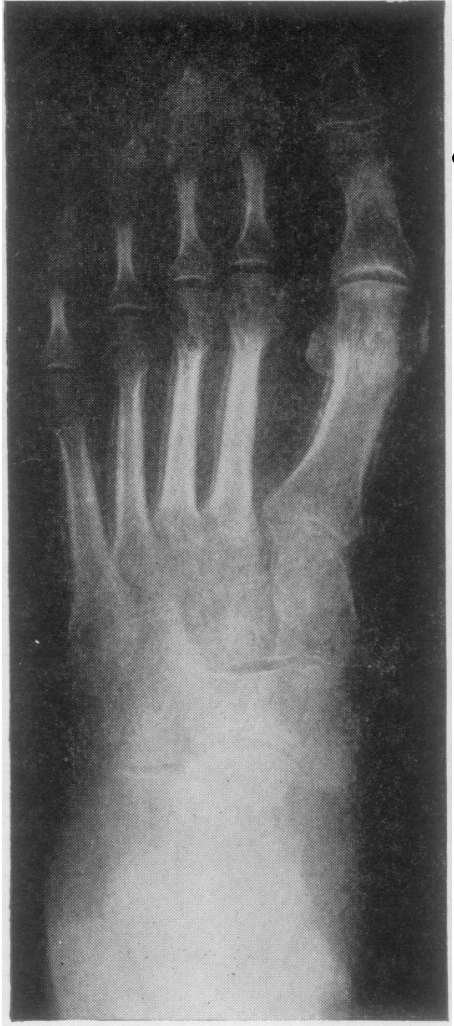

FIG. 4. Case 3. Radiograph of left foot shows extensive subperiosteal new bone formation.

amputation a few months previously. The chest radie graph (Fig. 5) showed multiple bilateral pulmonat. metastases.

\section{DISCUSSION}

Pulmonary osteoarthropathy is a syndrome characterized by painful symmetrical arthropath with swelling of the distal thirds of the arms and legs. Severe clubbing of the fingers and toes and subperiosteal new bone formation are usuallos present. Gynaecomastia is present in some cases (Hammarsten and O'Leary, 1957 ; Bariéty and Coury, 1950; Yacoub, 1965a). The pathologic雨 changes have been described by Gall, Bennett, and Bauer (1951). Increased blood flow to the affected limbs has been demonstrated (Charr and Swenso $\mathbb{P}$ 1946 ; Mendlowitz, 1941 ; Ginsburg, 1958). All the available evidence suggests that the syndrome $\vec{B}$ produced by a reflex mechanism with the afferent impulses carried from the chest by the vagus 


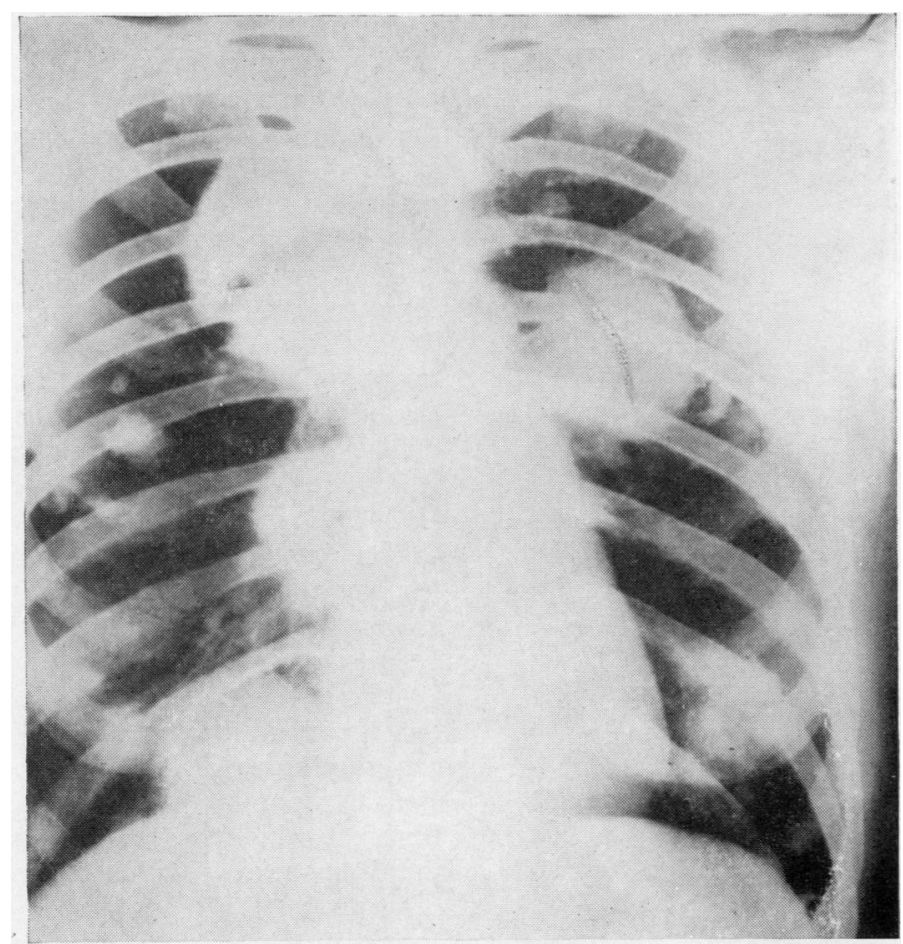

FIG. 5. Case 3. Chest radiograph shows bilateral multiple secondary deposits.

nerve; the efferent pathways are not known (Flavell, 1956; Huckstep and Bodkin, 1958; Coury, 1960 ; Holling, Brodey, and Boland, 1961 ; Yacoub, 1965a).

Although pulmonary osteoarthropathy can occur with a wide variety of intrathoracic conditions, certain diseases tend to be associated with it more commonly than others. Osteoarthropathy can be secondary to intrathoracic inflammatory conditions, including empyema, lung abscess, pulmonary blastomycosis, and pulmonary aspergillosis (Locke, 1915 ; Compere, Adams, and Compere, 1935; Yacoub and : Simon, 1966). Pulmonary tuberculosis is sometimes associated with clubbing of the fingers (Poppe, 1947 ; Kaplan and Munson, 1941 ; Neufeld and Wallbank, 1952), but osteoarthropathy is rarely secondary to it (Skorneck and Ginsburg, 1958 ; Yacoub and Simon, 1966).

Intrathoracic tumours are the commonest cause of pulmonary osteoarthropathy. According to Coury (1960) lung cancer (primary or metastatic) accounts for $80 \%$ of the cases, pleural tumours for $10 \%$, and other intrathoracic tumours for $5 \%$. The reported incidence of pulmonary osteoarthropathy in bronchial carcinoma varies in different series; in a group of 200 patients studied by one of us the incidence was 4\% (Yacoub, 1965b). In an attempt to determine the incidence of pulmonary osteoarthropathy in cases of metastatic tumours of the lung, Aufses and Aufses (1960) examined the records of 883 patients with pulmonary metastases at the Montefiore Hospital, New York. None of these patients had clinical evidence of pulmonary osteoarthropathy ; one had periosteal new bone and 34 had clubbing of the fingers. Fibrous tumours of the pleura are associated with pulmonary osteoarthropathy in $66 \%$ of cases (Clagett, McDonald, and Schmidt, 1952 ; Price Thomas and Drew, 1953; Benoit and Ackerman, 1953).

The incidence of pulmonary osteoarthropathy in association with bronchial carcinoma is related to the cell type (Yacoub, 1965b). No similar relationship has been described in cases of metastatic pulmonary tumours. This is probably due to the rarity of the condition and the paucity of reported cases; 41 cases, including the patients described here, have been reported (see Table). Analysis of these showed that metastasis from osteosarcoma accounts for $30 \%$ of cases, from 
T A B L E

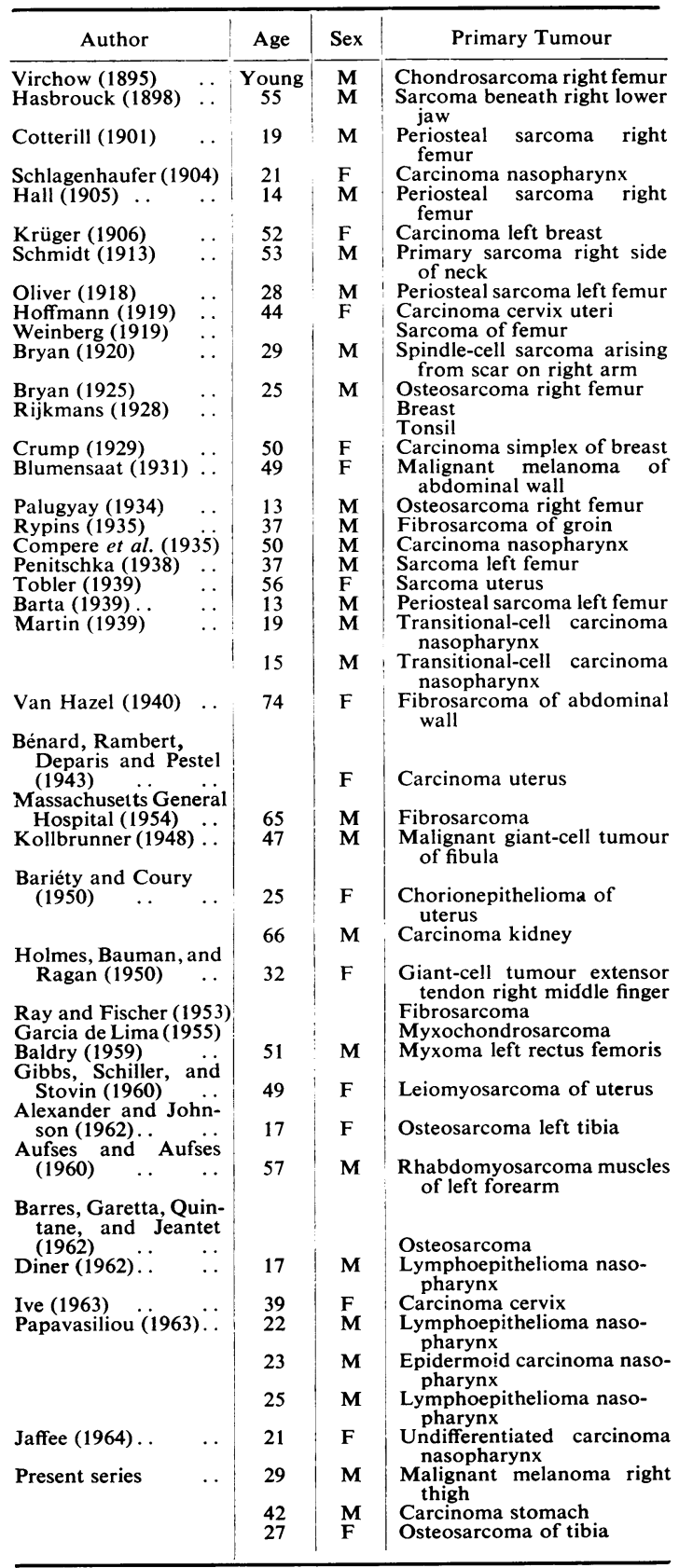

fibrosarcoma for $17 \%$, from nasopharyngeal tumours for $19.1 \%$, from uterine tumours for $12.7 \%$, and from tumours of other regions for $21 \cdot 2 \%$. Together, osteosarcoma and fibrosarcoma account for $47 \%$ of cases. The relationship be- tween pulmonary metastasis from nasopharyngea $\overrightarrow{F_{0}}$ tumours and osteoarthropathy has been pointe $\Phi^{5}$ out by Papavasiliou (1963), who commented orf the young age of the patients affected, the hila position of the pulmonary metastases, and the्D regression of symptoms after irradiation of the pulmonary metastases. Out of four patients witle pulmonary metastases from nasopharyngea tumours seen by the same author, three had osteoarthropathy. Osteoarthropathy secondary to pulmonary metastases from nasopharyngea

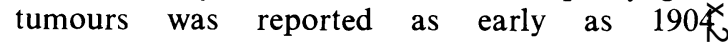
(Schlagenhaufer, 1904) and later by Compere $e^{\mathrm{N}}$ al. (1935), Martin (1939), Diner (1962), and Jaffe (1964).

The factors which determine the ability of ao tumour to produce pulmonary osteoarthropathy are not known. The vascularity of the tumour has been suggested as an important factor (Mend lowitz, 1941 ; Aufses and Aufses, 1960). Against this theory is the fact that the very vascular oatg cell carcinoma is seldom if ever associated with osteoarthropathy (Yacoub, 1965b), whereas pleurab fibroma, which has a lower vascularity, is coms monly associated with osteoarthropathy. The rate of growth of the tumour is not a factor, since्ष some of the most rapidly growing tumours are associated with osteoarthropathy which car develop in a very short time. Fibrous tumour (pleural fibroma, pulmonary metastasis from fibro sarcoma, and tumours with a predominantly. fibrous stroma (pulmonary metastasis from osteo sarcoma)) tend to be associated with osteo arthropathy more than other tumours. This sugx gests that the fibrous stroma may be a factor in stimulating the reflex responsible for osteo; arthropathy. This is supported by the fact that oat-cell carcinoma, which lacks a fibrous stroma is never associated with osteoarthropathy.

\section{REFERENCES}

Alexander, C. P., and Johnson, V. W. (1962). Hypertrophic pulmorfo ary osteoarthropathy associated with pulmonary metastases removed surgically. Postgrad. med. J., 38, 173.

Aufses, A. H., and Aufses, B. H. (1960). Hypertrophic osteoarthr? pathy in association with pulmonary metastases from extrE thoracic malignancies. Dis. Chest, 38, 399.

Bamberger, E. (1889). 'Case report'. Wien. klin. Wschr., 2, 226. Baldry, P. E. (1959). Cavitation in pulmonary sarcomatous metastase

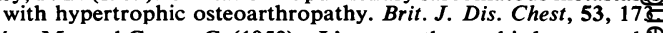

Bariéty, M., and Coury, C. (1950). L'osteo-arthropathie hypertroph $\$$ ante pneumique et les dysacromélies d'origine thoracique Aspects anatomo-cliniques et évolutifs. Sem. Hôp. Paris, 26, 1681

Barres, J., Garetta, L., Quintane, G., and Jeantet, R. (1962). Exuberant pulmonary hypertrophic osteoarthritis of rapid development aftę the metastatic spread of an osteosarcoma. (French.) Bull. Soф
Méd. franc., 56, 77.

Barta, R. (1939). Ein eigenartige Fall von Pierre Mariescher Kran1 heit. Wien. klin. Wschr., $52,254$.

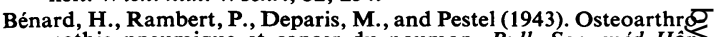
pathie pneumique et cancer du poumon. Bull. Soc. méd Hốp. Paris, 59, 132. 
Benoit, H. W., and Ackerman, L. V. (1953). Solitary pleural mesotheliomas. J. thorac. Surg., 25, 346.

Berg, R., Jr. (1949). Arthralgia as a first symptom of pulmonary lesions. Dis. Chest, 16, 483.

Blumensaat, C. (1931). Ostéoarthropathie hypertrophiante pneumique (Pierre-Marie). Röntgenpraxis, 3, 134

Bryan, L. (1920). Secondary hypertrophic osteo-arthropathy with metastatic sarcoma of the lung. Amer. J. Roentgenol., 7, 286. (1925). Secondary hypertrophic osteoarthropathy following metastatic sarcoma of the lung. Calif. west. Med., 23, 449.

Charr, R., and Swenson, P. C. (1946). Clubbed fingers. Amer. J. Roentgenol., 55, 325.

Clagett, O. T., McDonald, J. R., and Schmidt, H. W. (1952). Localized fibrous mesothelioma of the pleura.J. thorac. Surg., 24, 213.

Compere, E. L., Adams, W. E., and Compere, C. L. (1935). Generalized hypertrophic osteoarthropathy: An experimental and clinical study with report of two cases. Surg. Gynec. Obstet., 61, 312.

Cotterill, J. M. (1901). Case of hypertrophic osteopathy of hands and foot following amputation at the hip joint for sarcoma. Scot. med. surg. J., $8,47$.

Coury, C. (1960). Hippocratic fingers and hypertrophic osteoarthropathy. A study of 350 cases. Brit. J. Dis. Chest, 54, 202.

Craig, J. W. (1937). Hypertrophic pulmonary osteoarthropathy as the first symptom of pulmonary neoplasm. Brit. med.J., 1, 750 .

Crump, C. (1929). Histologie der allgemeinen Osteophytose (Ostéoarthropathie hypertrophiante pneumique). Virchows Arch. path. Anat., 271, 467.

Diner, W. C. (1962). Hypertrophic osteoarthropathy. Relief of symptoms by vagotomy in a patient with pulmonary metastases from a lympho-epithelioma of the nasopharynx. J. Amer. med. Ass. 181,555 .

Editorial. (1954). The hand. Brit. med. J., 1, 384.

Flavell, G. (1 )56). Reversal of pulmonary hypertrophic oesteoarthropathy by vagotomy. Lancet, $1,260$.

Gall, E. A., Bennett, G. A., and Bauer, W. (1951). Generalized hypertrophic osteoarthropathy: a pathologic study of seven cases. Amer.J.Path., 27, 349.

Garcia de Lima, F. D. (1955). Osteopatia tóxica hipertrófica associada a mixocondrosarcoma pulmonar metastático: Descrição de un caso. Mem. Inst. Osw. Cruz, 53, 573.

Gibbs, D. D., Schiller, K. F. R., and Stovin, P. G. I. (1960). Lung metastases heralded by hypertrophic pulmonary osteoarthropathy. Lancet, 1,623 .

Ginsburg, J. (1958). Observations on the peripheral circulation in hypertrophic pulmonary osteoarthropathy. Quart. J. Med., 27, 335.

Hall, D. G. (1905). Hypertrophic pulmonary osteo-arthropathy, with an account of two cases. Edinb. med. J., New Series, 18, 127.

Hammarsten, J. F., and O'Leary, J. (1957). The features and significance of hypertrophic osteoarthropathy. Arch. intern. Med., 99, 431.

Hasbrouck, E. M. (1898). A case of hypertrophic pulmonary osteoarthropathy. N.Y. med. J., 67, 665 .

Hoffmann, V. (1919). Ein Beitrag zur Kenntnis der Osteoarthropathie hypertrophiante pneumique (P. Marie). Dtsch. Arch. klin. Med., 130, 201.

Holling, H. E., Brodey, R. S., and Boland, H. C. (1961). Pulmonary hypertrophic osteoarthropathy. Lancet, 2, 1269.

Holmes, H. H., Bauman, E., and Ragan, C. (1950). Symptomatic arthritis due to hypertrophic pulmonary osteoarthropathy in pulmonary neoplastic disease. Ann. rheum. Dis., 9, 169.

Huckstep, R. L., and Bodkin, P. E. (1958). Vagotomy in hypertrophic pulmonary osteoarthropathy associated with bronchial carcinoma. Lancet, $2,343$.

Ive, F. A. (1963). Metastatic carcinoma of cervix with acanthosis nigricans, bullous pemphigoid and hypertrophic pulmonary osteoarthropathy. Proc, roy. Soc. Med., 56, 910.

Jaffee, I. S. (1964). Nasopharyngeal carcinoma. Unusual case reports. Arch. Otolaryng., 80, 450.

Kaplan, R. H., and Munson, L. (1941). Clubbed fingers in pulmonary tuberculosis. Amer. Rev. Tuberc., 44, 439.
Kollbrunner, F. (1948). Gutartiger Riesenzelltumor mit maligner Entartung nach 4 Jahren und Osteoarthropathie hypertrophiante pneumique durch Lungenmetastase. Oncologia (Basel), 1, 153.

Krüger (1906). Zur Kenntnis der Ostéoarthropathie hypertrophiante pneumique. Virchows Arch. path. Anat., 185, 43.

Locke, E. A. (1915). Secondary hypertrophic osteo-arthropathy and its relation to simple club-fingers. Arch. intern. Med., 15, 659.

Marie, P. (1890). De l'ostéo-arthropathie hypertrophiante pneumique Rev. Méd. (Paris), 10, 1

Martin, C. L. (1939). Complications produced by malignant tumors of the nasopharynx. Amer. J. Roentgenol., 41, 377.

Massachusetts General Hospital (1945). Case 31271. New Engl. J. Med., 233, 18.

Mendlowitz, M. (1941). Clubbing and hypertrophic osteoarthropathy. Medicine (Baltimore), 21, 269.

Neufeld, O., and Wallbank, W. L. (1952). Clubbed fingers. Ohio St. med. J., 48, 834.

Oliver, P. (1918). Metastatic sarcoma of lung with hypertrophic pulmonary osteo-arthropathy. Surg. Clin. Chicago, 2, 361.

Palugyay, J. (1934). Zur Ätiologie und Röntgendiagnostik der Knochensarkome nebst einem Beitrag zur Osteoarthropathie hypertrophiante pneumique. Fortschr. Röntgenstr., 50, 107.

Papavasiliou, C. G. (1963). Pulmonary metastases from cancer of the nasopharynx associated with hypertrophic osteoarthropathy. Brit. J. Radiol., 36, 680.

Penitschka, W. (1938). Uber Osteoarthropathie hypertrophiante (Bamberger-Marie). Bruns' Beitr. klin. Chir., 167, 75.

Poppe, J. K. (1947). The diagnostic significance of clubbed fingers. Dis. Chest, 13, 658 .

Price Thomas, C., and Drew, C. E. (1953). Fibroma of the visceral pleura. Thorax, 8, 180.

Ray, E. S., and Fischer, H. P., Jr. (1953). Hypertrophic osteoarthropathy in pulmonary malignancies. Ann. intern. Med., 38, 239.

Rijkmans, J. C. (1928). Bijdrage tot de Kennis van de Acropachie (Osteoarthropathie hypertrophiante pneumique). Diss, Groningen.

Rypins, E. L. (1935). Hypertrophic osteo-arthropathy. Radiology, 25, 289.

Schlagenhaufer, F. (1904). Uber diffuse ossifizierende Periostitis. Z. Heilk., 25, Abt. path. Anat., p. 364.

Schmidt, M. B. (1913). Hyperplastische Periostitis. Aschaffs. Lehrb. d. path. Anat.

Semple, T., and McCluskie, R. A. (1955). Generalized hypertrophic osteoarthropathy in association with bronchial carcinoma. Brit. med. J., $1,754$.

Skorneck, A. B., and Ginsburg, L. B. (1958). Pulmonary hypertrophic osteoarthropathy (periostitis): its absence in pulmonary tuberculosis. New Engl. J. Med., 258, 1079.

Thompson, H. E. S. (1904). Hypertrophic pulmonary osteo-arthropathy. Med. chir. Trans., 87, 85.

Tobler, H. (1939). U'ber Ostéoarthropathie hypertrophiante pneumique (Bamberger-Pierre Marie). Inaug. Diss, Zürich. Reinhardt, Basel.

Van Hazel, W. (1940). Joint manifestations associated with intrathoracic tumours. J. thorac. Surg., 9, 495.

Virchow, R. (1895). Veränderungen des Skelets durch Akromegalie. Berl. klin. Wschr., 32, 1102.

Vogl, A., Blumenfeld, S., and Gutner, L. B. (1955). Diagnostic significance of pulmonary hypertrophic osteoarthropathy. Amer. J. Med., 18, 51 .

Weinberg, F. (1919). Zur Kenntnis der allgemeinen Periostitis hyperplastica. Anat. Hefte, 57, abt. 1, p. 623.

Yacoub, M. H. (1965a). Cervical vagotomy for pulmonary osteoarthropathy. Brit. J. Dis. Chest, 59, 28.

- (1965b). Relation between the histology of bronchial carcinoma and hypertrophic pulmonary osteoarthropathy. Thorax, 20, 537 and Simon, G. (1966). Hypertrophic pulmonary osteoarthropathy and intrathoracic inflammatory conditions. Brit. J. Dis. Chest, 60, 81 . 